\title{
Effect of Humic Acid Foliar Application on Quantitative and Qualitative Yield of Caraway (Carum carvi L.) Plant
}

\author{
Omer, A.A. ${ }^{1}$; ${ }^{\text {I.H. El-Sallami }}{ }^{2}$; M.M. Gad ${ }^{2}$ and A.A. Abdel-Kader ${ }^{1}$
}

${ }^{1}$ Hort. Res. Inst., Agric. Res. Center, Giza, Egypt.

${ }^{2}$ Floriculture Dept., Fac. Agric., Assiut Univ., Egypt.

*Email: Ismailelsallami@agric.au.edu.eg

Received on: $14 / 6 / 2020$

Accepted for publication on: $17 / 6 / 2020$

Abstract

A field trial was carried out during 2018/2019 and 2019/2020 seasons at the Experimental Farm of Faculty of Agriculture, Assiut University to study the effect of foliar humic acid application at the concentrations of 0 (control), 200 and 400 ppm three times, monthly interval on growth, fruit yield, and essential oil yield and its composition of caraway (Carum carvi L.) plant.

The results indicated that humic acid treatments improved the vegetative growth characteristics (plant height, branch number per plant and plant dry weight), fruit measurements (umbel number, 1000-seed weight and seed yield) and essential oil parameters (oil percentage, oil yield and oil constituents) in comparison with control plant (without humic acid). However, a rate of $400 \mathrm{ppm}$ was more effective than the level of $200 \mathrm{ppm}$ in this regard.

Seeds of plants received $400 \mathrm{ppm}$ showed the highest contents of total proein, total carbohydrates, total phenolics, ascorbic acid (vitamin $\mathrm{C}$ ) and thiamine (vitamin $B_{1}$ ). In contrast, these seeds contained the lowest levels of nitrate and nitrite. These findings were closely correlated with increasing 1000-seed weight showing better quality.

Chemical analysis of caraway leaves cleared that the maximum contents of nitrogen, phosphorus, potassium, and pigment were occurred by humic acid at $400 \mathrm{ppm}$ resulting in significant increases compared to $200 \mathrm{ppm}$ level in most cases. It was found a positive relationship between the highest contents of leaf $\mathrm{N}$, $\mathrm{P}$ and $\mathrm{K}$ and the improvement of vegetative growth and fruit characteristics, consequently increase of seed production.

The gas liquid chromatography (GLC) analysis of the essential oil showed the presence of two main components, carvone and limonene. The highest carvone $(40.58 \%)$ and the lowest limonene $(13.51 \%)$ were obtained by humic acid at $400 \mathrm{ppm}$, meanwhile the control showed the reverse trend; the lowest carvone $(18.86 \%)$ and the highest limonene $(23.60 \%)$. The level of 200 ppm showed intermediate contents. The quality of caraway seeds is considered to correlate with carvone/limonene ratio; the higher ratio expressed as better-quality. Accordingly, the best treatment achieved the highest ratio (3.0). It was observed a direct relationship among the increases of seed yield, essential oil and their qualities.

In addition, there were other components of the volatile oil present in small amounts such as myrcene, fenchone, camphonon,6, carveol, linalool, anethole, estragole and caryophyllen oxide.

It could be recommended to spray caraway plants with humic acid at 400 ppm 3 times, monthly intervals for its superiority via enhancing vegetative 
growth, improving yield and quality of seeds and essential oil, as well as chemical composition of caraway plants.

Keywords: Caraway, humic acid, vegetative growth, seed yield, essential oil.

Introduction

Carawy (Carum carvi L.) is one of the important aromatic plants belongs to Apiaceae family. The dried fruit (seeds) contain approximately 1 $6 \%$ essential oil, with carvone and limonene are the dominant components (Guenther, 1961). Caraway seeds and their essential oil have several medicinal purposes as carminative, mild stomachic and antispasmodic as a tonic in the treatment of digestive disorders. Dried fruits are widely employed for favoring bread, cake confectionery, cheese and kinds of food products (Weiss, 1997).

Humic acid is found to improve the productivity of the aromatic seed crops quantitatively and qualitatively comparing with the chemical fertilizers. The utilization of humic acid as natural nutrients helps to improve yield and quality traits of medicinal and aromatic plants characterized by safe production, besides reducing production costs and environmental pollution without reduction of yield (Gomma and Youssef, 2008; Acimovic et al., 2015b; Awad, 2016; Mahmoud et al., 2017; El-Banna and Fouda, 2018 and Hassan, 2019).

Many researchers have reported that humic acid recognized as a plant growth promoter by increasing the quality of crop and supply for plant nutrition, enhancing plant growth and development, as well as increasing the quantity of yield due to its essential action on physiological and metabolic processes (Eyheraguibel et al., 2008 and Asik et al., 2009). The positive effects of humic acid on cell membrane functions by promoting nutrient uptake, respiration, nucleic acid biosynthesis, ion absorption, and enzyme activity as hormone-like substances (Nardi et al., 2002).

Therefore the objective of the present work was to investigate the benefit effects of humic acid application on vegetative growth, fruit yield, essential oil content and its composition, as well as some active biochemical constituents and nutrient elements content to achieve safe caraway production.

\section{Materials and Methods}

An open field experiment was carried out at the Experimental Farm of Faculty of Agriculture, Assiut University during two continual seasons $(2018 / 19$ and $2019 / 20)$ to investigate the effects of humic acid on quantitative and qualitative characteristics of caraway (Carum carvi L.) plant as a trial to improve its growth and productivity.

Seeds of caraway were obtained from Horticulture Research Institute, Agric. Research Center, Giza, Egypt and sown in a clay soil for two seasons in October $25^{\text {th }} 2018$ and 2019 in plots $2 \times 1.5 \mathrm{~m}$ with three rows at 50 $\mathrm{cm}$ apart in each plot and $25 \mathrm{~cm}$ between the seed hills within the row. Six weeks after, the thinning was done leaving two seedlings per hill (36 plant/plot). A total of caraway plants was approximately 48000 per feddan. Some physico-chemical properties of field cultivation soil are shown in Table (A). The averages of ambient temperatures ranging between 20 and $35^{\circ} \mathrm{C}$, as well as the 
relative humidity between 70 and $75 \%$ in the study area during the period of experimentation. All horticulture practices as irrigation, weeding and fungicides treatment were similarly done whenever needed. No fertilizers and herbicides were supplied to soil.
The potassium humate used in this study having a physical data as follows: appearance (black powders), $\mathrm{pH} \quad(9-10)$ and water solubility (>98\%). The quarated analysis were as follow: Humic acid $90 \%$ and $\mathrm{K}_{2} \mathrm{O}$ $10 \%$.

Table A. Physico-chemical properties of the experimental soil.

\begin{tabular}{|c|c|c|c|}
\hline \multirow{2}{*}{\multicolumn{2}{|c|}{$\begin{array}{r}\text { Physical properties } \\
\text { Particle size distribution }\end{array}$}} & \multicolumn{2}{|l|}{ Chemical properties } \\
\hline & & Total carbonate $(\%)$ & 3.10 \\
\hline \multirow[t]{2}{*}{ Clay } & 44.6 & Sulfur (ppm) & 195.00 \\
\hline & & Phosphorus (mg P/100 gm soil) & 2.54 \\
\hline \multirow[t]{2}{*}{ Silt } & 35.0 & Sodium (\%) & 0.48 \\
\hline & & Potassium (meq/100 gm soil) & 59.50 \\
\hline \multirow[t]{2}{*}{ Sand } & 20.4 & Calcium (meq/100 gm soil) & 18.70 \\
\hline & & Chloride $(\%)$ & 0.86 \\
\hline \multirow[t]{2}{*}{ Soil texture } & Clay & Magnesium (meq/100 gm soil) & 11.40 \\
\hline & & Total nitrogen $(\%)$ & 0.065 \\
\hline \multirow[t]{2}{*}{$\mathrm{CaCO}_{3}(\%)$} & 3.10 & $\mathrm{pH}$ (suspension of $1: 2.5 \mathrm{w} / \mathrm{w}$ soil : water) & 7.65 \\
\hline & & $\mathrm{EC} \mathrm{dS} / \mathrm{m}$ (water extract of $1: 5 \mathrm{w} / \mathrm{w}$ soil : water) & 0.61 \\
\hline \multirow[t]{2}{*}{ Organic matter $(\%)$} & 1.32 & DTPA-Extractable (ppm): & \\
\hline & & $\mathrm{Fe}$ & 9.7 \\
\hline \multirow[t]{2}{*}{ Field capacity (F.C) \% } & 41.2 & $\mathrm{Mn}$ & 10.3 \\
\hline & & $\mathrm{Zn}$ & 1.2 \\
\hline
\end{tabular}

Humic acid at the concentration of 0 (control), 200 and $400 \mathrm{ppm}$ were applied in aqueous solutions as foliar spray after 60,90 and 120 days from sowing corresponding February, March and April, respectively, in 2019 and 2020. The foliar spray application was done using air compressed hand sprayer to the point of run-off in the early morning. The untreated plants (control) were sprayed with tap water. Triton B wetting agent was used at a rate $1 \mathrm{ml} / \mathrm{l}$ as a surfactant immediately before spraying.

\section{Data recorded}

Caraway fruits (seeds) were harvested at full ripeness in May of both seasons. Data were recorded at the end of experiments (27 weeks from sowing) on vegetative characteristics; plant height, number of branches per plant, plant dry weight and root-shoot ratio (was calculated by dividing root dry weight by shoot one), as well as seed measurements (number of umbles per plant, 1000seed weight, seed yield per plant and per feddan).

\section{Chemical analysis}

The chemical constituents of $\mathrm{N}$, $\mathrm{P}$ and $\mathrm{K}$ contents in leaves, as well as total protein, total carbohydrates, total phenolics, nitrate and nitrite contents in the harvested seed at full ripeness were measured in the dry material. The wet digestion of $0.1 \mathrm{~g}$ plant material with sulphuric and per- 
chloric acids was done to determine leaf nutrient elements $(\mathrm{N}, \mathrm{P}$ and $\mathrm{K})$, as well as nitrogenous compounds (total nitrogen, $\mathrm{NO}_{3}^{-}$and $\mathrm{NO}_{2}^{-}$) in seeds according to Baruah and Barthakur (1997). Nitrogen was determined colorimetrically at $400 \mathrm{~nm}$ wavelength using the Nessler's reagent method described by Allen (1959). Protein content in seeds was quantified and calculated using the conversion factor of 6.25 based on the assumption that the protein contains $16 \%$ nitrogen according to Ranganna (1978). Nitrate $\left(\mathrm{NO}_{3}^{-}-\mathrm{N}\right)$ was estimated spectro-photometrically at $410 \mathrm{~nm}$ as described by Cataldo et al. (1975), as well as nitrite $\left(\mathrm{NO}_{2}^{-}-\mathrm{N}\right)$ at $520 \mathrm{~nm}$ according to Hesse (1994). Phosphorus was determined colorimetrically at $660 \mathrm{~nm}$ using stannous chloride phosphomolibdicsulphuric acid system according to Jackson (1978). Potassium was determined in the digested solution using Flame-photometer model 52 with acetylene burner according to Jackson (1978). Total carbohydrates in seed was measured colorimetrically by anthrone sulphuric acid method at $630 \mathrm{~nm}$ according to Hansen and Moller (1975). Leaf pigments (chlorophyll "a", chlorophyll "b" and carotenoids) contents were measured by spectrophotometer and calculated according to the equations described by Vernon (1960). Total phenolics content was determined spectrophotometrically at $750 \mathrm{~nm}$ using a modified Folin-Ciocalteu reagent assay according to Strail et al. (2006).

\section{Determination of vitamins}

Vitamin $\mathrm{C}$ as ascorbic acid was determined in seeds according to Bajaj and Kaur (1981). Assays of thia- mine (vitamin $\mathrm{B}_{1}$ ) in caraway seeds were carried out using a method described by Rapala-Kozik et al. (2008).

\section{Extraction of the essential oil}

Essential oil contents of caraway seeds $(50 \mathrm{~g})$ were extracted by the hydro-distillation method for two hours according to U.S.P. (1995); essential oil percentage yield per plant and per feddan were calculated.

Analysis of essential oil composition

Gas liquid chromatography (GLC) analysis of caraway essential oil was carried out using gas chromatograph (Hewlett Packard GC. Model 5890) equipped with a flam ionization detector (FID). A fused silica (HP-5MS) capillary column $(30 \mathrm{~m}$ length, $0.53 \mathrm{~mm}$ internal diameter "i.d.", $0.88 \mathrm{~mm}$ film thickness) was used for the separation in the GC. The identification of the different constituents was achieved by comparing their retention times with those of the authentic samples according to the methods outlined by Singh et al. (2006).

\section{Statistical analysis}

The obtained data in both seasons of the study were exposed to analysis of variance as a complete randomized design with five replicates using Statistix 8.1 analytical software, and the means were compared using a least significant difference (L.S.D.) test according to Dowdy and Wearden (1983).

\section{Results and Discussion}

Vegetative growth characteristics

Data presented in Table 1 showed that treatments of humic acid foliar application improved plant growth parameters expressed as plant 
height, number of branches per plant and plant dry weight. Spraying caraway plants with humic acid at 400 ppm was more effective than 200 ppm level resulting in significant increases in these characters compared to control (without humic) which gave the lowest values in both seasons. Meanwhile, humic acid showed insignificant effect on root /shoot ratio. These results are in harmony with those obtained on caraway plant by Gomaa and Youssef (2008), Awad (2016), Mahmoud et al. (2017) and Hassan (2019).

The superiority of plant growth with addition of humic acid might be attributed to its vital role in supply the plants major and minor nutrient elements require for promoting plant metabolism and development. It can improve plant growth directly by accelerate the proteosynthesis, and increasing water and nutrient uptake and yields of plants (Panda, 2006). Humic acid is also assumed to increase the chlorophyll content of green plants, and hence can be used to control chlorosis and improve photosynthesis (Nardi et al., 2002). The role of humic acid in stimulating plant growth is by the enzyme activation, changes in membrane permeability and the activation of biomass production (Ulukan, 2008). In addition, foliar spray with humic acid reduces the transpiration rate, and this in turn leads to keep high water content in the plant tissues and hence might favor the plant metabolism, the physiological processes, photosynthetic rate and many other important functions that directly affect the plant growth (Tan, 2011). Humic acid can provide protection against some toxic growth inhibiting substances introduced in the soil (Arun, 2002).

Table 1. Growth characteristics of caraway plants as affected by humic acid levels during the two seasons of 2018/19 and 2019/20.

\begin{tabular}{|c|c|c|c|c|c|c|c|c|}
\hline \multirow{2}{*}{$\begin{array}{l}\text { Humic acid } \\
\qquad(\mathrm{ppm})\end{array}$} & \multicolumn{2}{|c|}{$\begin{array}{l}\text { Plant height } \\
\text { (cm) }\end{array}$} & \multicolumn{2}{|c|}{$\begin{array}{c}\text { Branch } \\
\text { No./plant }\end{array}$} & \multicolumn{2}{|c|}{$\begin{array}{l}\text { Whole plant } \\
\text { dry weight (g) }\end{array}$} & \multicolumn{2}{|c|}{ Root/shoot ratio } \\
\hline & $1^{\text {st }}$ & $2^{\text {nd }}$ & $1^{\text {st }}$ & $2^{\text {nd }}$ & $1^{\text {st }}$ & $2^{\text {nd }}$ & $1^{\text {st }}$ & $2^{\text {nd }}$ \\
\hline 0 (Control) & 112.2 & 97.4 & 11.9 & 15.0 & 22.23 & 23.00 & 0.199 & 0.215 \\
\hline 200 & 113.2 & 103.6 & 12.1 & 15.9 & 23.98 & 25.77 & 0.188 & 0.197 \\
\hline 400 & 117.4 & 117.2 & 13.2 & 16.9 & 27.21 & 28.18 & 0.179 & 0.188 \\
\hline L.S.D. 0.05 & 5.1 & 5.3 & 1.2 & 1.3 & 4.57 & 3.76 & N.S & N.S \\
\hline
\end{tabular}

\section{Seed (fruit) yield}

Foliar application of humic acid had a significant effect on all seed yield parameters especially at a rate of $400 \mathrm{ppm}$ compared to control in both seasons (Table 2). This increment in spraying caraway plants with humic acid may be due to stimulate plant growth through availability of nutrients for plants which reflected on increasing number of umbels per plant (37.9 in average), weight of 1000 seeds $(5.88 \mathrm{~g})$ and seed yield $(12.12 \mathrm{~g} /$ plant and $582 \mathrm{~kg} / \mathrm{fed})$. These results are parallel to the results of Gomaa and Youssef (2008) and Acimovic et al. (2015a) on caraway, Sharaf-El-Deen et al. (2012) on fennel, Safaei et al. (2014) on black 
cumin, and Beyzi et al. (2017) on coriander.

Furthermore, the increase of seed yield per plant and per feddan resulted from humic application could be due to increase in the num- ber of umbels formed by plant and the weight of 1000 seeds. Such effects of humic acid on fruit yield may be attributed to synthesis of metabolites used in fruit formation.

Table 2. Seed (fruit) measurement of caraway as affected by humic acid levels during the two seasons of 2018/19 and 2019/20.

\begin{tabular}{|c|c|c|c|c|c|c|c|c|}
\hline \multirow{2}{*}{$\begin{array}{c}\text { Humic acid } \\
(\mathbf{p p m})\end{array}$} & \multicolumn{2}{|c|}{ Umbel No./plant } & \multicolumn{1}{|c|}{$\begin{array}{c}\mathbf{2 0 0 0} \text { seed-weight } \\
\mathbf{( g )}\end{array}$} & \multicolumn{2}{c|}{$\begin{array}{c}\text { Seed yield } \\
(\mathbf{g} / \mathbf{p l a n t})\end{array}$} & \multicolumn{2}{c|}{$\begin{array}{c}\text { Seed yield } \\
(\mathbf{k g} / \mathbf{f e d})\end{array}$} \\
\cline { 2 - 9 } & $\mathbf{1}^{\text {st }}$ & $\mathbf{2}^{\text {nd }}$ & $\mathbf{1}^{\text {st }}$ & $\mathbf{2}^{\text {nd }}$ & $\mathbf{1}^{\text {st }}$ & $\mathbf{2}^{\text {nd }}$ & $\mathbf{1}^{\text {st }}$ & $\mathbf{2}^{\text {nd }}$ \\
\hline $\mathbf{0}(\mathbf{C o n t r o l )}$ & 31.8 & 26.4 & 4.61 & 5.77 & 7.78 & 8.09 & 373.5 & 388.4 \\
\hline $\mathbf{2 0 0}$ & 33.2 & 34.5 & 4.73 & 6.27 & 9.70 & 10.08 & 465.7 & 484.0 \\
\hline $\mathbf{4 0 0}$ & 35.8 & 40.0 & 5.29 & 6.46 & 11.87 & 12.37 & 569.8 & 593.9 \\
\hline L.S.D. 0.05 & 3.5 & 5.1 & 0.36 & 0.31 & 1.41 & 2.06 & 67.6 & 93.5 \\
\hline
\end{tabular}

\section{Seed quality in relation to chemical composition}

There were significant increases in the chemical composition of caraway seeds including protein, carbohydrate and phenolic contents as the level of applied humic acid raised compared to control in both seasons (Table 3). These components are accumulated in seed tissues at $400 \mathrm{ppm}$ level was much than 200 ppm resulting in 22.6 and $21.5 \%$ for total contents of protein and carbohydrates, respectively, as well as total phenlic compounds $(2.9 \mathrm{mg} / \mathrm{g}$ D.M. as average). In the contrary, the high humic acid rate recorded the lowest concentrations of nitrate and nitrite averaging 652.5 and $75.9 \mu \mathrm{g} / \mathrm{g}$ D.M., respectively.

Numerous researchers revealed that humic acid application play a major role in stimulation the physiology and biochemical quality of seeds. Humic acid as foliar spray proved to be ideal and suitable organic source for better protein synthesis as increased significantly with increasing the rate as mentioned by Eyheraguibel et al. (2008) in maize grains, Asik et al. (2009) in wheat grains and Vijayakumari et al. (2012) on soybean seeds. On caraway, Gomaa and Yousef (2008) and Mahmoud et al. (2017) stated that supplied plants with humic acid increased total carbohydrate and phenolic compounds content in seeds. El-Banna and Fouda (2018) reported that seed quality was correlated with high concentration of total nitrogen and reductions of nitrate and nitrite contents in caraway seeds. 
Table 3. Chemical composition of caraway seeds as affected by humic acid levels during the two seasons of 2018/19 and 2019/20.

\begin{tabular}{|c|c|c|c|c|c|c|c|c|c|c|}
\hline \multirow[t]{2}{*}{$\begin{array}{l}\text { Humic acid } \\
\quad(\text { ppm) }\end{array}$} & \multicolumn{2}{|c|}{$\begin{array}{c}\text { Total protein } \\
\%\end{array}$} & \multicolumn{2}{|c|}{$\begin{array}{l}\text { Total carbohy- } \\
\text { drates } \%\end{array}$} & \multicolumn{2}{|c|}{$\begin{array}{c}\text { Total pheno- } \\
\text { lics } \\
\text { (mg/g D.M) }\end{array}$} & \multicolumn{2}{|c|}{$\begin{array}{c}\mathrm{NO}_{3}^{-}-\mathrm{N} \\
(\mu \mathrm{g} / \mathrm{g} \text { D.M. })\end{array}$} & \multicolumn{2}{|c|}{$\begin{array}{c}\mathrm{NO}_{2}-\mathrm{N} \\
(\mu \mathrm{g} / \mathrm{g} \text { D.M. }\end{array}$} \\
\hline & $1^{\text {st }}$ & $2^{\text {nd }}$ & $1^{\text {st }}$ & $2^{\text {nd }}$ & $1^{\text {st }}$ & $2^{\text {nd }}$ & $1^{\text {st }}$ & $2^{\text {nd }}$ & $1^{\text {st }}$ & $2^{\text {nd }}$ \\
\hline 0 (Control) & \begin{tabular}{|l|}
18.38 \\
\end{tabular} & 19.43 & 14.33 & 13.61 & 1.66 & 2.33 & 780 & 800 & 110.8 & 111.8 \\
\hline 200 & 20.35 & 21.49 & 17.00 & 17.51 & 2.08 & 2.76 & 703 & 720 & 90.0 & 90.8 \\
\hline 400 & 21.88 & 23.25 & 20.76 & 22.22 & 2.51 & 3.31 & 645 & 660 & 75.5 & 76.2 \\
\hline L.S.D. 0.05 & 0.66 & 1.03 & 1.21 & 1.33 & 0.09 & 0.14 & 40 & 37 & 5.3 & 5.4 \\
\hline
\end{tabular}

It is quite clear that humic acid at $400 \mathrm{ppm}$ had a positive influence on filling caraway fruits in high order umbels and this can be the consequence of high contents of total protein, total carbohydrates and other organic compounds, as well as optimal absorptions of essential macro- and micronutrients during periods of fruit formation and ripening to attain their full potential. These results were similar to those obtained by Bewley and Black (1994). Moreover, a general explanation was on the basis of more carbohydrates which closely correlated with a marked increase in vegetation. This specific finding led to increase in photosynthesis activity, consequently producing more photosynthetic products and carbohydrate accumulation. The adaptation of oil production dependent on maintaining high carbohydrates. These observations are supported by the findings of Sangwan et al. (2001).

Some workers emphasized that phenolic compounds have important roles in the physiological and biochemical processes of seeds. Among the most significant functions of the phenolics are their accumulation in seeds may be metabolically create an adaptive role by restricting the growth and development of seeds against DNA-damaging storage. Phenolic may act as disease resistance mechanism in seeds, and influence competition among plants by producing toxins such as cinnamate (Vallee and Falchuk, 1993).

As evident from the results of this work, humic acid at $400 \mathrm{ppm}$ showed higher ascorbic acid (vitamin C) and thiamine (vitamin $B_{1}$ ) in caraway seeds by 43 and $39 \%$, respectively over control (Fig. 1). These results corroborate with the findings of Mahmoud et al. (2017) on caraway. Other authors declared that humic acid as foliar application increased vitamin $\mathrm{C}$ content in pea seeds (Gad et al., 2012) and in soybean seeds (Vijayakumari et al., 2012) as well as increased thiamine content in peanut seeds (Moraditochaee, 2012) and in wheat grains (Radwan et al., 2015). 

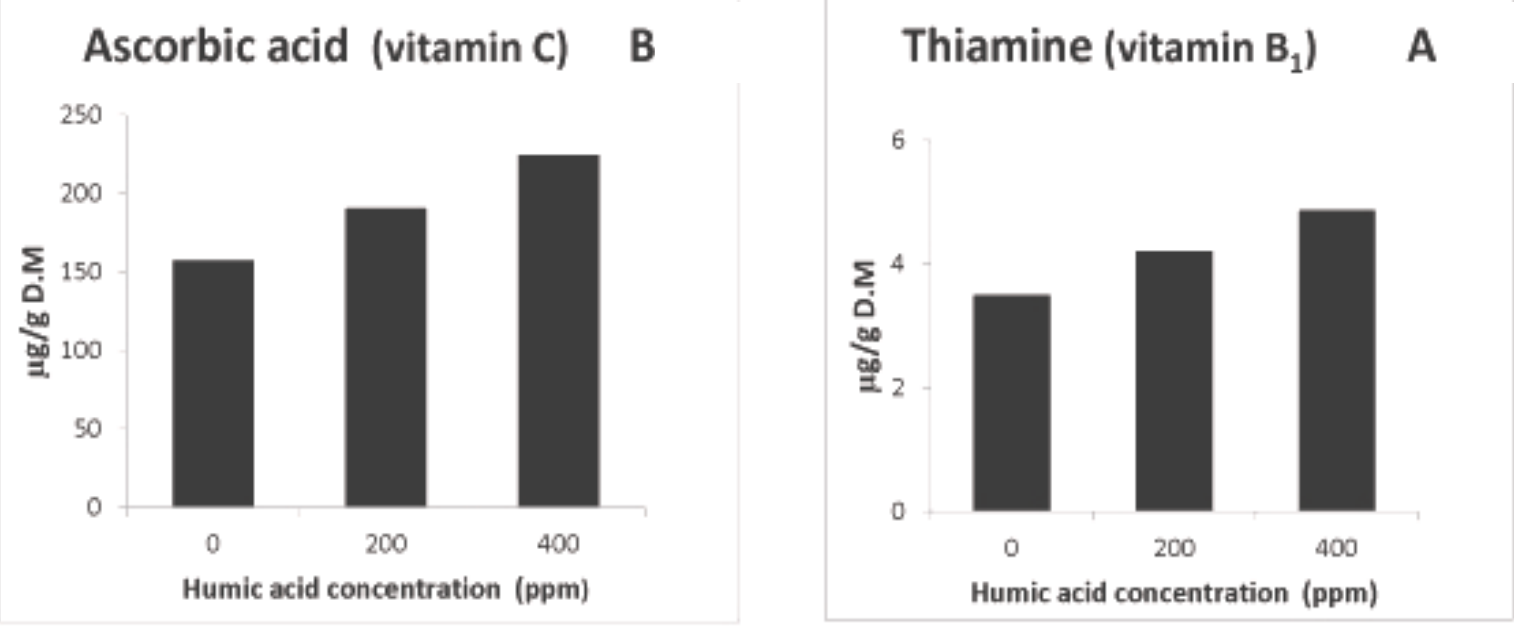

Fig. 1. Effect of humic acid levels on ascorbic acid and thiamine contents in Caraway seeds.

These increases of both vitamins could be related to the stimulative effects of humic acid on the adequate nutritional status that is essential for maintaining the optimal activities of all physiological processes. Thus, humic acid at 400 ppm proved to be more sufficiently active to absorb the amounts of nutrient elements at adequate levels reflected genetically controlled enhancement in mechanism of mineral nutrition which were obviously in close relationship to the best growth of caraway plans. It is also necessary for chlorophyll synthesis, carbohydrate formation since it combines with protein to promote endogenous hormones synthesis, whereas the positive association exists among them to metabolically create beneficial effects or regulate possibly both vitamins content in caraway seeds. These observations are in agreement with the opinions of many authors applied humic acid (Juárez et al., 2011; Chamani et al., 2015 and Mahmoud et al., 2017).

On the other hand, the biosynthesis of both vitamins were correlated with the regulation of the me- tabolism of soluble carbohydrate (Golda et al., 2004), increased energy generation for the synthesis of proteins (Belanger et al., 1995), acceleration of DNA synthesis (Ajjawi et al., 2007), increased endogenous hormones levels of IAA and GA, and decreased ABA (Raschke et al., 2007) and activities of antioxidant enzymes (Rapala-Kozik et al., 2008), as well as play specialized roles against DNA damage or pathogen attack (Ahn et al., 2005).

\section{Essential oil content}

Studying essential oil (Table 4), it was obvious that humic acid at 200 and $400 \mathrm{ppm}$ had a positive effect on oil formation whereas the higher level markedly greater than the lower one resulting in significant increases in oil percentage and yield in comparison with a rate of $200 \mathrm{ppm}$ or control in both seasons. The highest percentage and yield obtained by foliar humic acid application at $400 \mathrm{ppm}$ were 3.29 and $3.46 \%, 0.40$ and $45 \mathrm{ml} /$ plant and 19.16 and $21.68 \mathrm{l} / \mathrm{fed}$ as average for the first and second seasons, respectively. These results are in conformity with those reported by Go- 
maa and Youssef (2008), Acimovic et al. (2015b), Awad (2016) and Mahmoud et al. (2017) on caraway.

The beneficial effect of humic acid on essential oil formation due to the direct function of humic acid on solubilization and transport of nutrient elements which enhance the vegetative growth characteristics and play an important role in synthesis of plant constituents such as essential oil. The sufficient availability of these elements might be led to higher seed yield and consequently higher essential oil yield as mentioned by Parry (1985).
In this concern, Sangwan et al. (2001) concluded that the production of essential oil not only depends upon the metabolic state and present developmental differentiation programme of the synthesizing tissue, but also highly integrated with the physiology of the whole plant. Besides, the oil productivity is friendly to ecophysiological, environmental and other factors. All these aspects of the modulation of essential oil production must be taken into consideration.

Table 4. Essential oil productivity of caraway seeds as affected by humic acid levels during the two seasons of 2018/19 and 2019/20.

\begin{tabular}{|l|c|c|c|c|c|c|}
\hline \multirow{2}{*}{ Humic acid (ppm) } & \multicolumn{2}{|c|}{ Essential oil \% } & \multicolumn{2}{c|}{$\begin{array}{c}\text { Essential oil yield } \\
\text { (ml/plant) }\end{array}$} & \multicolumn{2}{c|}{$\begin{array}{c}\text { Essential oil yield } \\
\text { (1/fed) }\end{array}$} \\
\cline { 2 - 7 } & $\mathbf{1}^{\text {st }}$ & $\mathbf{2}^{\text {nd }}$ & $\mathbf{1}^{\text {st }}$ & $\mathbf{2}^{\text {nd }}$ & $\mathbf{1}^{\text {st }}$ & $\mathbf{2}^{\text {nd }}$ \\
\hline $\mathbf{0}$ (Control) & 2.51 & 2.70 & 0.20 & 0.23 & 9.56 & 10.90 \\
\hline $\mathbf{2 0 0}$ & 2.90 & 3.08 & 0.29 & 0.33 & 13.77 & 15.84 \\
\hline $\mathbf{4 0 0}$ & 3.29 & 3.46 & 0.40 & 0.45 & 19.16 & 21.68 \\
\hline L.S.D. 0.05 & 0.20 & 0.51 & 0.05 & 0.16 & 2.33 & 6.09 \\
\hline
\end{tabular}

$1^{\text {st }}$ : First season $2^{\text {nd }}:$ Second season.

\section{Essential oil constituents}

There were 38 compounds determined in caraway essential oil (Table 5), among them there were two main components, carvone and limonene, whose mixture in this experiment constituted from 42.46 to 54.09 of total oil composition. The highest percentage of carvonene + limonene mixture was resulted from humic acid at a concentrate of 400 ppm $(54.09 \%)$ followed by $200 \mathrm{ppm}$ level $(46.39 \%)$, meanwhile the lowest percentage of the mixture was obtained by control $(42.46 \%)$. Whereas, humic acid at $400 \mathrm{ppm}$ increased car- vone and decreased limonene percentages in caraway essential oil, contrast to this the control. These results are in agreement with those reported on caraway oil by Acimovic et al. (2014) and Mahmoud et al. (2017). Furthermore, GLC analyses for all components showed the presence of myrcene, fenchone camphonone, 6, carveol, linalool, anethole, astragole, caryophyllene oxide and others were present in small amounts in the seeds volatile oil. Similar results were obtained by Diab (2007) and El-Tarawy et al. (2017). 
Table 5. Essential oil constituents (\%) and carvone/limonene ratio in caraway seeds as affected by humic acid levels during 2019/2020 season.

\begin{tabular}{|c|c|c|c|c|}
\hline \multirow{2}{*}{ Compound (\%) } & \multirow{2}{*}{ R.T. (min.) } & \multicolumn{3}{|c|}{ Humic acid levels (p.p.m.) } \\
\hline & & 0 (control) & 200 & 400 \\
\hline A-pinene & 4.74 & 0.09 & 0.15 & 0.67 \\
\hline Bicycle $(3-1,3)$ hexane & 5.59 & 1.14 & 0.86 & 0.25 \\
\hline Myrcene & 6.02 & 1.19 & 2.01 & 4.56 \\
\hline Limonene & 7.00 & 23.60 & 20.90 & 13.51 \\
\hline Fenchone & 8.47 & 1.38 & 2.66 & 6.22 \\
\hline Cyclohexene-1-01 & 9.37 & 1.57 & 2.65 & 3.36 \\
\hline trans-limonene oxide & 9.84 & 4.60 & 2.57 & 1.33 \\
\hline Camphonone,6- & 10.56 & 0.42 & 0.31 & 0.22 \\
\hline Cyclohexene-1-Menthone & 11.54 & 0.69 & 1.40 & 2.78 \\
\hline cis-Dihydro carvone & 11.68 & 0.77 & 2.75 & 3.63 \\
\hline Carveol & 12.13 & 0.36 & 0.41 & 0.46 \\
\hline Carvone & 12.99 & 18.86 & 25.49 & 40.58 \\
\hline Cyclohexene-1-one & 13.59 & 2.63 & 5.27 & 8.90 \\
\hline Octadienal,3,7-dimethyl & 13.93 & 0.36 & 0.50 & 1.03 \\
\hline Cyclohexene-1-carboxal & 14.04 & 1.29 & 1.48 & 1.64 \\
\hline Anethole & 14.20 & 0.21 & 0.24 & 1.08 \\
\hline Estragole & 14.21 & 0.24 & 1.67 & 1.85 \\
\hline Trimethlbicyclo & 14.42 & 0.35 & 0.18 & 0.13 \\
\hline p-Mentha-1,8-dien & 14.47 & 0.94 & 0.35 & 0.25 \\
\hline (35,6R)-3-Hydroperoxy & 14.68 & 2.19 & 1.06 & 0.44 \\
\hline$\alpha$-Farnesene & 15.25 & 0.50 & 0.28 & 0.14 \\
\hline 1,2-cyclohexanediol & 15.44 & 1.03 & 0.83 & 0.67 \\
\hline Bicyclohexyl-2-one & 16.27 & 2.22 & 0.18 & 0.06 \\
\hline Naphthol & 17.24 & 0.43 & 0.26 & 0.25 \\
\hline Caryophyllene oxide & 17.45 & 0.58 & 0.14 & 0.12 \\
\hline Benzene,1,4-dimethoxy-2-methyl & 17.58 & 7.84 & 3.78 & 1.48 \\
\hline Humulene & 18.29 & 0.16 & 0.24 & 0.32 \\
\hline Cyclodecadiene & 18.99 & 0.63 & 0.48 & 0.18 \\
\hline Naphthalene & 19.11 & 0.51 & 0.38 & 0.27 \\
\hline$\alpha$-Selinene & 19.33 & 0.43 & 0.52 & 0.62 \\
\hline Germacrene A & 19.57 & 0.74 & 0.64 & 0.57 \\
\hline Isoaromadendrene & 21.03 & 0.20 & 0.12 & 0.07 \\
\hline Salvial-4 (14)-En-1-one & 21.68 & 0.42 & 0.54 & 0.33 \\
\hline Aromadendrene oxid & 22.90 & 0.18 & 0.20 & 0.24 \\
\hline Neointermedol & 23.07 & 0.49 & 0.16 & 0.17 \\
\hline Trans-Longipinocarveol & 24.56 & 0.00 & 0.11 & 0.12 \\
\hline Hexadecanoic acid & 39.10 & 1.72 & 0.00 & 0.00 \\
\hline Linalool & 39.30 & 1.72 & 0.00 & 0.00 \\
\hline Other minor components $(\%)$ & & 2.38 & 1.37 & 0.74 \\
\hline Carvone+Limonene mixture (\%) & & 42.46 & 46.39 & 54.09 \\
\hline Carvone/Limonene ratio & & 0.80 & 1.22 & 3.00 \\
\hline
\end{tabular}

R.T.-retention time

values are mean of three replicates. 
Interestingly, there is evidence that biosynthesis of carvon and limonene occurs via the same pathway. This implies that limonene in both an intermediate in the biosynthesis of carvone, as well as the end product (Bouwmeester et al., 1995). As shown in Table 5, humic acid at 400 ppm showed the dominant compound in caraway essential oil is carvon $(40.58 \%)$ and the lowest limonene content (13.51\%). These findings indicated that humic acid which would in turn favour formation of carvone to formation limonene. These results support previous observations (Acimovic et al., 2015b and Awad, 2016). These authors postulated that humic acid can change plant behavior regarding the biosynthesis of bioactive compounds whereas induced an increase in the carvone proportion and decrease in limonene proportion, but did not affect the chemotype of caraway essential oil.

The overall quality of caraway seeds is considered to correlate with the content of essential oil and its carvone/limonene $(\mathrm{C} / \mathrm{L})$ ratio; the higher ratio expressed as betterquality (Kallio et al., 1994). Humic acid at $400 \mathrm{ppm}$ achieved the highest $\mathrm{C} / \mathrm{L}$ ratio (3.0). Therefore, it can be concluded that caraway tested under humic acid application belongs to cravone chemotype. In contrast, the control showed the lowest $\mathrm{C} / \mathrm{L}$ ratio $(0.8)$, this indicated that the quality of essential oil was poor. However, humic acid at $200 \mathrm{ppm}$ resulted in intermediate ratio (1.22).

\section{Leaf nutrients and pigments}

Data presented in Table 6 indicated that treatments of humic acid foliar application had a significant effect on leaf contents of nitrogen, phosphorus and potassium compared to control in both seasons. However, a rate of $400 \mathrm{ppm}$ was more effective resulting in significantly higher concentrations of these nutrient elements than a level of $200 \mathrm{ppm}$. These results are coordination with the findings of Gomaa and Youssef (2008), Awad (2016), Mahmoud et al. (2017), ElBanna and Fouda (2018) and Hassan (2019) on caraway.

In this scenario, Stevenson (1994) reported that the interpretation of all molecular weights of humic acid can be absorbed and show evidence that the uptake is dependent on the active component of transport. Aiken et al. (1985) demonstrated that the effects of humic acid on ion uptake appear to be more or less selective and variable, in relation to their concentration and to the $\mathrm{pH}$ of the medium. Chen et al. (2004) stated that the effects of humic acid on ion absorption by plant roots are not easily explainable. It is possible that thumic acid exert several effects on plant functions and some of these may result, directly or indirectly, in a modulation of ion uptake. 
Table 6. Leaf nutrients and pigments as affected by humic acid levels during the two seasons of $2018 / 19$ and $2019 / 20$.

\begin{tabular}{|c|c|c|c|c|c|c|c|c|c|c|c|c|}
\hline \multirow{2}{*}{$\begin{array}{l}\text { Humic acid } \\
\text { (ppm) }\end{array}$} & \multicolumn{2}{|c|}{$\begin{array}{c}\text { Nitrogen } \\
\%\end{array}$} & \multicolumn{2}{|c|}{$\begin{array}{c}\text { Phosphorus } \\
\%\end{array}$} & \multicolumn{2}{|c|}{$\begin{array}{c}\text { Potassium } \\
\%\end{array}$} & \multicolumn{2}{|c|}{$\begin{array}{l}\text { Chlorophyll } \\
\text { "a" (mg/g) }\end{array}$} & \multicolumn{2}{|c|}{\begin{tabular}{|c|} 
Chlorophyll \\
"b" (mg/g)
\end{tabular}} & \multicolumn{2}{|c|}{$\begin{array}{c}\text { Carotenoids } \\
(\mathrm{mg} / \mathrm{g})\end{array}$} \\
\hline & $1^{\text {st }}$ & $2^{\text {nd }}$ & $1^{\text {st }}$ & $2^{\text {nd }}$ & $\mathbf{1}^{\text {st }}$ & $2^{\text {nd }}$ & $1^{\text {st }}$ & $2^{\text {nd }}$ & $1^{\text {st }}$ & $\mathbf{2}^{\text {nd }}$ & $1^{\mathrm{st}}$ & $2^{\text {nd }}$ \\
\hline 0 (Con & 2.54 & 2.59 & 0.351 & 0.354 & 2.62 & 2.60 & 1.246 & 1.343 & 0.351 & 0.430 & 0.363 & 0.354 \\
\hline 200 & 2.82 & 2.88 & 0.373 & 0.392 & 2.90 & 2.92 & 1.4 & 1.495 & (1 & 0.477 & 6 & 0.381 \\
\hline 400 & 3.03 & 3.11 & 0.419 & 0. & 3.19 & 3.35 & 1.792 & 1.835 & 0.459 & 0.593 & 4 & 45 \\
\hline L.S.I & 0.14 & 0.14 & 0.018 & 0.006 & 0.15 & 0.13 & 0.256 & 0.295 & 0.088 & 0.129 & 0.051 & 0.074 \\
\hline
\end{tabular}

Concerning leaf pigments, it was observed that humic acid treatments significantly increased chlorophyll "a", chlorophyll "b" and carotenoids compared to control in both seasons (Table 6). However, a level of $400 \mathrm{ppm}$ was significantly higher than a rate of $200 \mathrm{ppm}$ in relation to leaf pigments in most cases. These results coincided with Gomaa and Youssef (2008), Mahmoud et al. (2017) and Hassan (2019) on caraway.

As evident from the results discussed above, findings presented the most pronounced treatment (400 ppm) was more sufficiently active to absorb the amount of such nutrient elements at adequate levels and translocated them towards the leaves as a site of accumulation resulted in the highest contents which were obviously in close relationship to the best growth that reflected on increasing leaf pigments content. The synthesis of chlorophyll is closely associated with the highest nitrogen content. Thomas et al. (2003) revealed that the production of leaf pigments was reduced in many plants when nitrogen is laking. An early and dramatic symptom of nitrogen deficiency is a general yellowing of leaves or chlorosis, due to an inhibition of chlorophyll synthesis.
It is interesting to note positive relationships among leaf pigments, carbohydrate accumulation and protein content in caraway seeds. Chlorophyll is a limited factor for the photosynthesis which take place in leaves, an increase in chlorophyll content was associated with increasing in carbohydrates synthesis as mentioned by Gibson (2005). Furthermore, nitrogen is expected from its major role as a constituents of protein and many coenzymes and interference with protein synthesis and hence with growth. The resulting slow-down of photosynthesis causes a nitrogen deficient to lake not only essential amino acids, but also the machinery for synthesis of necessary carbohydrates. A reduction of nitrogen in leaves causes photosynthesis fails to keep pace and a depletion of carbohydrates (Rajan, 2003).

Generally, it could be concluded that foliar application of humic acid three times after sowing at a rate of $400 \mathrm{ppm}$ was generally superior as a result of nutritious balance which closely reflected on highly seed yield and essential oil production with better-quality (high carvone and low limonene contents. In addition, improvement in the bioactive phytochemicals in the fruits including proteins, carbohydrates, phenols, ascor- 
bic acid (vitamin $\mathrm{C}$ ) and thiamine (vi$\operatorname{tamin} \mathrm{B}_{1}$ ); they are active constituents as antioxidants which were consistently greater, but accompanied with decreasing in nitrate and nitrite contents that produce high quality of caraway seeds. They were established efficiency on safety manner suitable for marketing and more economic, as well as umpolluted environment.

\section{References}

Acimovic, M.G.; F. Vladimir; S. Jovana; C. Mirjana and D. Lana (2015a). The influence of environmental conditions on Carum carvi L. seed quality. Ratar. Povit., 52 (3): 9196.

Acimovic, M.G.; S.I. Oljaca; V.V. Tesevic; M.M. Todosijevic and J.N. Djisalov (2014). Evaluation of caraway essential oil from different production areas of Serbia. HortSci., 41 (3): 122-130.

Acimovic, M.G.; Z.K. Dolijanovic; S.I. Oljaca; D.D. Kovacevic and M.V. Oljaca (2015b). Effect of organic and mineral fertilizers on essential oil content in caraway, anise and coriander fruits. Acta Sci. Pol. Hort. Cultus, 14 (1): 95-103.

Ahn, I.P.; S. Kim and Y.H. Lee (2005). Vitamin $B_{1}$ functions as an activator of plant disease resistance. Plant Physiol., 138: 1505-1515.

Aiken, G.R.; D.M. McKnight; R.L. Wershaw and P. MacCarthy (1985). Humic Substances in Soils, Sediments, and Water. Wiley Interscience, New York, USA, p. 608.

Ajjawi, I.; M.A. Rodriguez-Milla; J. Cushman and D.K. Shintani (2007). Thiamin pyrophosphokinase is required for thiamin cofactor activation in Arabidopsis. Plant Molecular Biol., 65: 151162.

Allen, O.N. (1959). Methods of determining nitrogen. In: Experiments in Soil Bacteriology. $3^{\text {rd }}$ ed., Burgees Publ. Co. Minneopolis, Minnesota, pp. 83-88.

Arun, K.S. (2002). A Handbook of Organic Farming. Pub. Agrobios, India, p. 669.

Asik, B.B.; M.A. Turan; H. Celik and A.V. Katkat (2009). Effects of humic substances on plant growth and mineral nutrients uptake of wheat (Triticum durum cv. Salihli) under conditions of salinity. Asian J. Crop Sci., 1 (2): 87-95.

Awad, M.Y.M. (2016). Poultry manure and humic acid foliar applications impact on caraway plants grown on a clay loam. J. Soil Sci. \& Agric. Eng., Mansoura Univ., 7 (1): $1-10$.

Bajaj, K.L. and G. Kaur (1981). Spectrophotometric determination of ascorbic acid in vegetables and fruits. Analyst 106: 117-120.

Baruah, T.C. and H.P. Barthakur (1997). A Textbook of Soil Analysis. Vikas Pub. House PVT Ltd, New Delhi, p. 334.

Belanger, F.C.; T. Leustek; B. Chu and A.L. Kirz (1995). Evidence for the thiamine biosynthetic pathway in higher plant plastids and its developmental regulation. Plant Molecular Bio., 29: 809-821.

Bewley, J.D. and M. Black (1994). Seeds: Physiology of Development and Germination. $2^{\frac{\text { nd }}{2}}$ ed. Plenum Press, New York, USA, pp. 367.

Beyzi, E.; A. Gunes and B. Gurbuz (2017). Effects of humic acid treatments on yield, morphological characteristics and essential oil components of coriander (Coriandrum sativum L.). Res. J. Soil Biol., 9 (1): 1-8.

Bouwmeester, H.J.; J.A.R. Davines; H.G. Smid and R.S.A. Welten (1995). Physiological limitations to carvone yield in caraway (Carum 
carvi L.). Industrial Crops and Products, 4: 39-51.

Cataldo, D.A.; M. Haroon; L.E. Schrader and V.L. Youngs (1975). Rapid colorimetric determination of nitrate in plant tissue by nitration of salicylic acid. Soil Sci. Plant Anal., 6: 71-80.

Chamani, E.; S.K. Ghalehtaki; M. Mohebodini and A. Ghanbari (2015). The effect of zinc oxide nanoparticles and humic acid on morphological characters and secondary metabolite production in Lilium ledebourii Bioss. Iranian J. Genet. \& Plant Breed., 4 (2): 11-19.

Chen, Y.; M. Nobili and T. Aviad (2004). Stimulatory effect of humic substances on plant growth. CRC Press. Boca Raton, Florida, USA, p. 435.

Diab, S.A.A. (2007). Effect of spraying with zinc and some amino acids on growth, yield, oil production and plant constituents of caraway ( $\mathrm{Ca}$ rum carvi L.) plants. M.Sc. Thesis, Fac. Agric., Cairo Univ., Egypt.

Dowdy, S. and S. Wearden (1983). Statistics for Research. John Wiley and Sons, New York, USA, p. 640.

El-Banna, H.Y. and K.F. Fouda (2018). Effect of mineral, organic, biofertilizers and humic acid on vegetative growth and fruit yield quality of caraway plants (Carum carvi L.). J. Soil Sci. \& Agric. Eng., Mansoura Univ., 9 (5): 237-241.

El-Tarawy, M.A.; M.A. Hegazi and E. Mahmoud (2017). Effect of bio, organic and chemical fertilization on growth, productivity and oil constituents of caraway (Carum carvi L.). J. Plant Production, Mansoura Univ., 8 (10): 993-997.

Eyheraguibel, B.; J. Silvestre and P. Mo$\mathrm{rad}$ (2008). Effects of humic substances derived from organic waste enhancement on the growth and mineral nutrition of maize. Biores. Technol., 99: 4206-4212.

Gad, S.H.; A.M. Ahmed and Y.M. Moustafa (2012). Effect of foliar application with two antioxidants and humic acid on growth, yield and yield components of pea (Pisum sativum L.). J. Hort. Sci. \& Ornamental Plants, 4 (3): 318-328.

Gibson, S.I. (2005). Control of plant development and gene expression by sugar signaling. Curr. Opin. Plant Biol. 8: 93-102.

Golda, A.; P. Szyniarowski; K. Ostrowska; A. Kozik and M. RapalaKozik (2004). Thiamine binding and metabolism in germinating seeds of selected cereals and legumes. Plant Physiol. \& Biochem., 42: 187-195.

Gomaa, A.O. and A.S.M. Youssef (2008). Efficiency of bio and chemical fertilization in presence of humic acid on growth performance of caraway. Proc. $4^{\text {th }}$ Scientific Conference, May 5-6 ${ }^{\text {th }}$, National Res. Centre, Agric. \& Biol. Res. Div., Cairo, Egypt.

Guenther, E. (1961). The Essential Oils. Van Nostrand Comp. Inc., New York, USA, Vol. I p. 262-306 \& IV p. 573-832.

Hansen, J. and I. Moller (1975). Percolation of starch and soluble carbohydrates from plant tissue for quantitative determination with anthrone. Analytical Biochemistry, 68 (1): 87-94.

Hassan, A.A. (2019). Effect of irrigation water salinity and humic acid treatments on caraway plants. J. Plant Prod., Mansoura Univ., 10 (7): 523-528.

Hesse, P.R. (1994). A Textbook of Soil Chemical Analysis. CBS Pub. \& Distributors, India, pp. 178-183.

Jackson, M.L. (1978). Soil Chemical Analysis. Fall Indian Private Ltd., New Delhi. 
Juárez, C.R.; L.E. Craker; N.R. Mendoza and J.A. Aguilar-Castillo (2011). Humic substances and moisture content in the production of biomass and bioactive constituents of Thymus vulgaris $\mathrm{L}$. Rev. Fitotec. Mex., 34 (3): 183-188.

Kallio, H.; A.K. Kerrolak and P. Alhonmaki (1994). Carvone and limonene in caraway fruits (Carum carvi L.) analyzed by supercritical carbon dioxide extraction-gas chromatography. J. Agric. and Food Chem., 42: 2478-2485.

Mahmoud, A.M.; A.B. El-Attar and A. Mahmoud (2017). Economic evaluation of nano and organic fertilizers as an alternative source to chemical fertilizers on Carum carvi L. plants yield and components. Agric. (Pol'nohospodárstvo) 63 (1): 33-49.

Moraditochaee, M. (2012). Effects of humic acid foliar spraying and nitrogen fertilizer management on yield of peanut (Arachis hypogacea L.) in Iran. Arpn J. Agric. \& Biol. Sci., 7 (4): 289-293.

Nardi, S.; D. Pizzeghello; A. Muscolo and A. Vianello (2002). Physiological effects of humic substances on higher plants. Soil Biol. \& Biochem., 34: 1527-1536.

Panda, S.C. (2006). Soil Management and Organic Farming. Agrobios (India) p. 462.

Parry, J.W. (1985). The Spice Handbook (spice, aromatic seeds and herbs). Brooklyn, N.Y: Chemical Publ. Co. Inc., pp. 254.

Radwan, F.I.; M.A. Gomaa; I.F. Rehab and S.I. Adam (2015). Impact of humic acid application, foliar micronutrients and biofertilization on growth, productivity and quality of wheat (Tritium aestivum L.). Middle East J. Agric. Res., 4 (2): 130-140.
Rajan, S.S. (2003). Plant Physiology. Annual Publications PVT. Ltd., New Delhi, India.

Ranganna, S. (1978). Manual of Analysis of Fruit and Vegetable Products. Tata McGraw-Hill Pub. Com. Limited, New Delhi, pp. 634.

Rapala-Kozik, M.; E. Kiowalska and K. Ostrowska (2008). Modulation of thiamine metabolism in Zea mays seedlings under conditions of abiotic stress. J. Exp. Botany, 59 (15): 4133-4143.

Raschke, M.; L. Burkle; N. Muller; A. Nunes-Nesi; A.R. Fernie; D. Arigoni; N. Amrhein and T.B. Fitzpatrick (2007). Vitamin $B_{1}$ biosynthesis in plants requires the essential iron sulfur cluster protein, THIC. Proc. Nat. Acad. Sci., USA 104: 19637-19642.

Safaei, Z.; M. Azizi; G. Davarynejad and H. Aroiee (2014). The effect of foliar application of humic acid and nanofertilizer on yield and yield components of black cumin (Nigella sativa L.). J. Medicinal Plants \& By-products 2: 133-140.

Sangwan, N.S.; A.H.A. Farooqi; F. Shabih and R.S. Sangwan (2001). Regulation of essential oil production in plants. Plant Growth Regul., 34: 3-21.

Sharaf-El-Deen, M.N.; H.Y. Massoud and M.A. Ahmed (2012). Effect of humic acid and fertilizers type on vegetative growth, fruit yield, essential oil quality of fennel (Foeniculum vulgare Mill.) plants. J. Plant Prod., Mansoura Univ., 3 (2): 201-215.

Singh, G.; S. Maurya; M. Lampasona and S. Catalan (2006). Chemical constituents, antifungal and antioxidative potential of Foeniculum vulgare volatile oil and its acetone extract. Food Control, 17: 745752. 
Stevenson, F.J. (1994). Humus Chemistry. Genesis, Composition, Reactions. $2^{\text {nd }}$ ed. Wiley \& Sons, New York, USA, p. 634.

Strail, P.; B. Klejdus and V. Kuban (2006). Determination of total content of phenolic compounds and their antioxidant activity in vegetables-evaluation of spectrophotometric methods. J. Agric. Food Chem., 54: 607-617.

Tan, K.H. (2011). Principles of Soil Chemistry. $4^{\text {th }}$ ed. CRC Press Taylor \& Francis Group, Boca Raton, London, p. 362.

Thomas, B.; D.J. Murphy and D. Murray (2003). Growth and Development: Growth Analysis, Individual Plants. Encyclopaedia of Appl. Plant Sci., Academic Press, London, pp. 588-596.

U.S.P. (1995). United States Pharmacopeia. Convention, INC.
Ulukan, H. (2008). Effect of soil applied humic acid at different sowing times on some yield components in wheat (Triticum spp.) hybrids. Inter. J. Botany 4 (2): 164-175.

Vallee, B.L. and K.H. Falchuk (1993). The biochemical basis of zinc physiology. Physiol. Rev., 73: 79118.

Vernon, L.P. (1960). Spectrophotometric determination of chlorophylls and pheophytins in plant extracts. Anal Chem., 32: 1144-1150.

Vijayakumari, B.; R.H. Yadav; P. Gowri and L.S. Kandari (2012). Effect of panchagavya, humic acid and micro herbal fertilizer on the yield and post harvest soil of soybean (Glycine $\max$ L.). Asian J. Plant Sci., 11 (2): 83-86.

Weiss, E.A. (1997). Essential Oil Crops. York House Typographic Ltd, London, UK, p. 600. 
تأثير الرش الورقي بحمض الهيوميك علي كمية ونوعية محصول نبات الكراوية

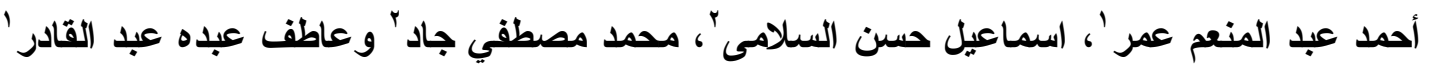

$$
\begin{aligned}
& \text { 'معهد بحوث البساتين - مركز البحوث الزر اعبة - الجيزة - مصر . }
\end{aligned}
$$

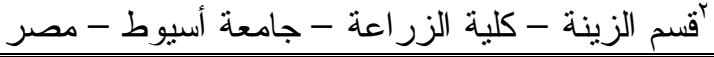

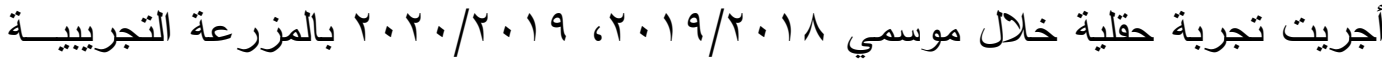

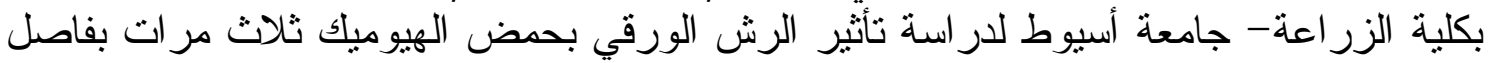

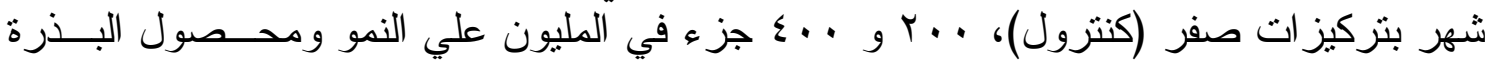

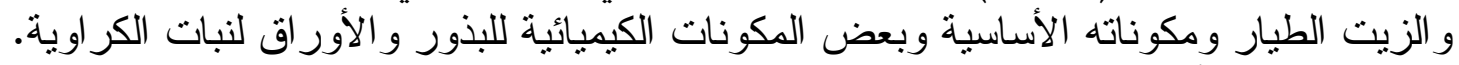

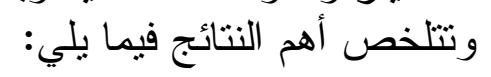

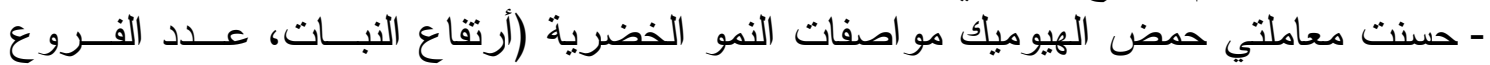

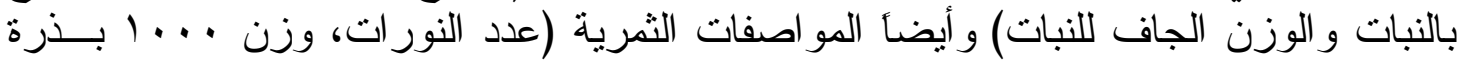

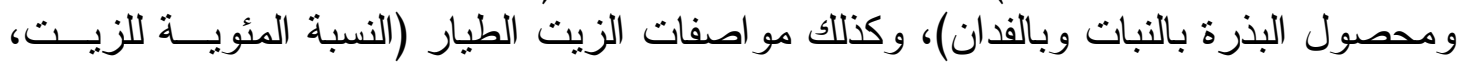
محصول الزيت بالنبات وبالفدان) بالمقارنة بالكنترول.

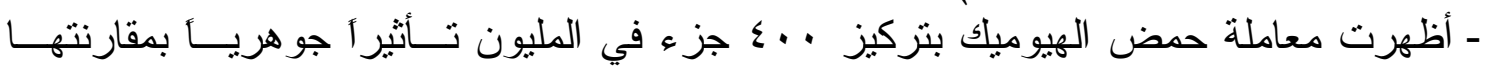

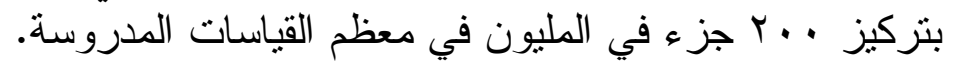

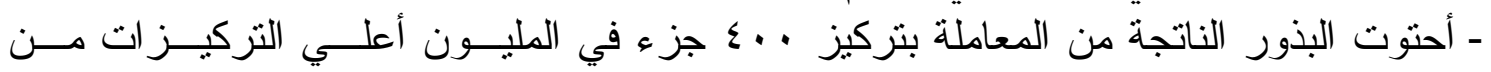

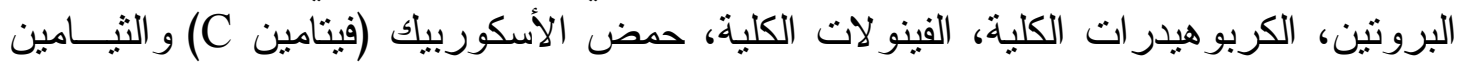

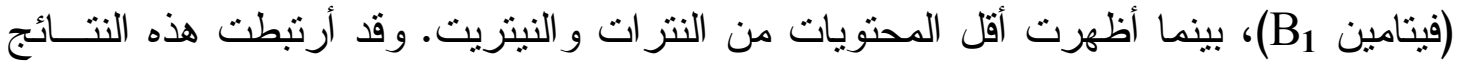

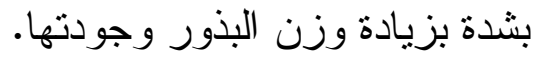

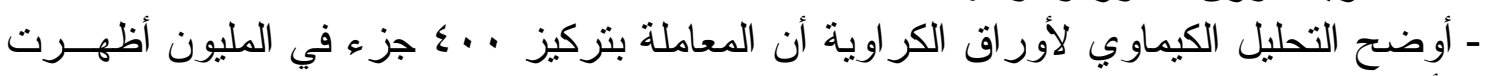

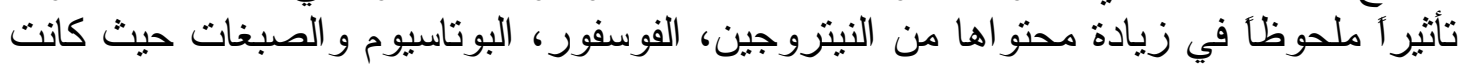

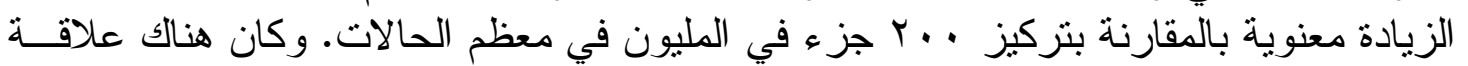

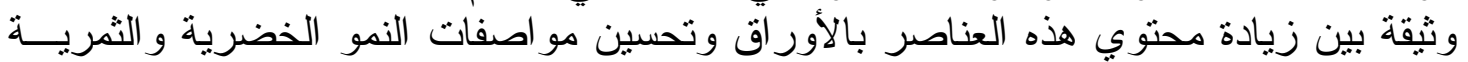
وبالتالي زيادة الإنتاج.

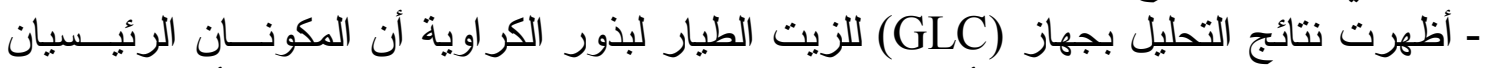

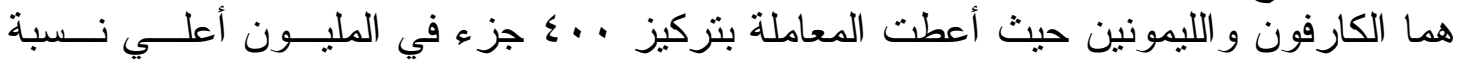

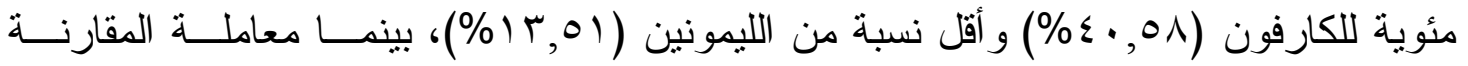

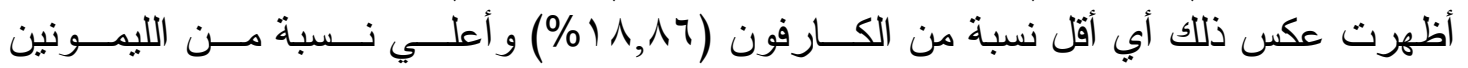

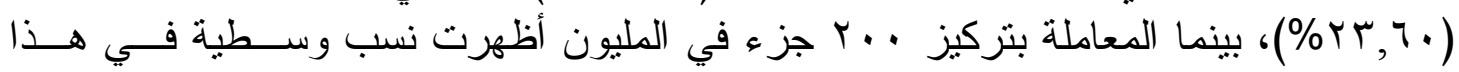

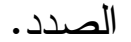

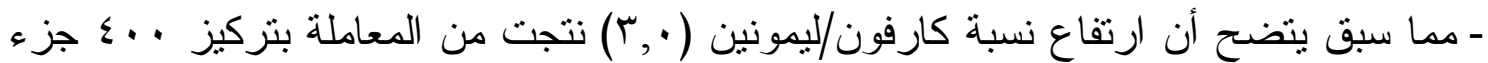

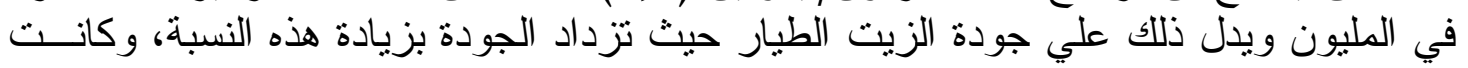

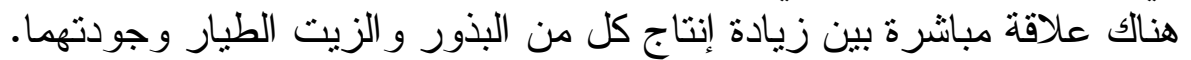

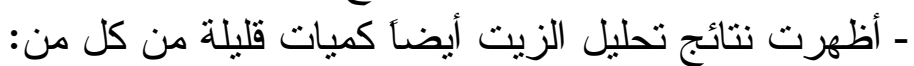
Myrcene, Fenchone, Camphonone, 6, Carveol, Linalool, Anethole, Estragole and Caryophyllene oxide.

- بناء علي نتائج هذه الدر اسة فإنه يوصي برش نباتات الكر اوية بحمض الهيوميك بتركيـز ل . .

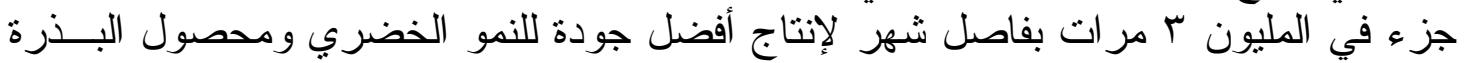
و الزيت الطيار و المحتوي الكيماوي لنباتات الكر اوية. 